\title{
$\mathrm{N}$-アリールアミジン類から若干のベンズ イミダソールの合成
}

\section{大曽根 基*・谷本重夫**.小田良平**}

Syntheses of Some Benzimidazoles from N-Arylamidines.

\author{
Motoi Ohosone*, Shigeo TAnimoto** and Ryohei ODA**
}

\begin{abstract}
Grenda's method to convert arylamidine hydrochloride into benzimidazole with the aid of sodium hypochloride and a base has been applied to the previously untried $\mathrm{N}$-arylamidines to synthesize the following : 5-chloro-2-phenylbenzimidazole $(\mathrm{Y}=96 \%), 5$-methyl-2-phenylbenzimidazole $(\mathrm{Y}=96 \%)$, 2-benzylbenzimidazole $(\mathrm{Y}=50 \%), 2$-benzyl-5-chlorobenzimidazole $(\mathrm{Y}=70 \%), 2-\left(2^{\prime}\right.$-naphthyl)-benzimidazole $(\mathrm{Y}=75 \%), 5$-chloro-2-(2'-naphthyl)-benzimidazole $(\mathrm{Y}=90 \%), 2$-( $p$-tolyl)benzimidazole $(\mathrm{Y}=95 \%), 5$-chloro-2- $(p$-tolyl $)$-benzimidazole ( $\mathrm{Y}=80 \%), 5$-methyl2 - $(p$-tolyl $)$-benzimidazole $(\mathrm{Y}=80 \%)$.
\end{abstract}

\section{I. 緒言}

ベンズアミジンに次亜塩素酸ナトリウムを作用させる と， N'ークロルベンズアミジンがえられることはよく知 られていることであるが, 最近 Grenda ら”はアニリン と 4-シアノチアゾールの Friedel-Crafts 反応によって $\mathrm{N}$-フェニル-4-チアゾールカルボキシアミジンを合成 し, これを次亜塩素酸ナトリウムで $\mathrm{N}^{\prime}$-クロル誘導体と し，さらに炭酸ナトリウムで処理することによって2(4'-チアゾリル)-ベンズイミダゾールをえている。同様

* 都島工業高等学校工業化学科 (大阪市都島区都島本 通)

* Department of Industrial Chemistry, Miyakojima Technical High School (Miyakojimahondouri, Miyakojima-ku, Osaka-shi)

** 京都大学工学部合成化学科 (京都市左京区吉田)

** Department of Synthetic Chemistry, Faculty of Engineering, Kyoto University (Yoshida, Sakyo$\mathrm{ku}, \mathrm{Kyoto}-\mathrm{shi}$ )
な方法で 2-フェニルベンズイミダゾールおよび 2-エチ ルベンズイミダゾールをもえている。そして，この方法 がベンズイミダゾールを合成する軽便な新手段であると 述べている。著者らは Grenda らが行っていない他のも， のについて，この方法を適用し比較的高収率で若干の心゙: ンズイミダゾールを合成したので報告する。

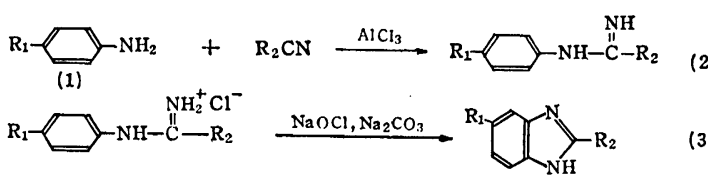

上式に拉いて，a） $\mathrm{R}_{1}=\mathrm{Cl}, \mathrm{R}_{2}=\mathrm{C}_{6} \mathrm{H}_{5}$; b) $\mathrm{R}_{1}=\mathrm{CH}_{3}$, $\mathrm{R}_{2}=\mathrm{C}_{6} \mathrm{H}_{5}$; c) $\mathrm{R}_{1}=\mathrm{H}, \mathrm{R}_{2}=\mathrm{C}_{6} \mathrm{H}_{5} \mathrm{CH}_{2}$; d) $\mathrm{R}_{1}=\mathrm{Cl}, \mathrm{R}_{2}=$ $\mathrm{C}_{6} \mathrm{H}_{5} \mathrm{CH}_{2}$; e) $\mathrm{R}_{1}=\mathrm{H}, \mathrm{R}_{2}=2-\mathrm{C}_{10} \mathrm{H}_{7}$;f) $\mathrm{R}_{1}=\mathrm{Cl}, \mathrm{R}_{2}=2-$ $\mathrm{C}_{10} \mathrm{H}_{7} ;$ g) $\left.\mathrm{R}_{1}=\mathrm{H}, \mathrm{R}_{2}=p-\mathrm{CH}_{3} \mathrm{C}_{6} \mathrm{H}_{4} ; \mathrm{h}\right) \mathrm{R}_{1}=\mathrm{Cl}, \mathrm{R}_{2}=$ $p-\mathrm{CH}_{3} \mathrm{C}_{6} \mathrm{H}_{4}$ ；i） $\mathrm{R}_{1}=\mathrm{CH}_{3}, \mathrm{R}_{2}=p-\mathrm{CH}_{3} \mathrm{C}_{6} \mathrm{H}_{4}$ の場合であ る。 


\section{II. 実験および結果}

1. $\mathrm{N}$-(p-クロルフェニル)-ベンズアミジン $\left(\boldsymbol{2}_{\mathrm{a}}\right)$ お よひ類似化合物 $\left(\mathbf{2}_{\mathrm{b}} \sim \mathbf{2}_{\mathrm{i}}\right)$ の合成 Grenda らの方法 ${ }^{1}$ に準じて合成した。すなわち，p-クロルアニリン $12.4 \mathrm{~g}$ $(0.097 \mathrm{~mol})$ とベンゾニトリル $10 \mathrm{~g}(0.097 \mathrm{~mol})$ をテ トラクロルエタン $38 \mathrm{ml}$ に溶解し, これに無水塩化アル ミニウム $13 \mathrm{~g}(0.097 \mathrm{~mol})$ を加え反応させ, Grenda ら の方法と全く同様に処理した。すなわち, 反応後, $5 \mathrm{~N}$ 水酸化ナトリウム水溶液に加え, 静置して油層を分液 し，水層を塩化メチレンで抽出して油層に合した。これ を無水炭酸カリウムで乾燥後, 乾燥塩酸ガスを通じた が，結晶が析出しなかったので，溶剂を減圧で留去し， 残留物をエチルアルコールに溶解し，これを大量の酶酸 エチルにかきまぜながら加えて，(2a) の塩酸塩を沈澱 させた。収量 $25 \mathrm{~g}$, 収率 $97 \%$ 。(2a $)$ の塩酸塩を水に溶 解し, これに炭酸ナトリウム水溶液を加えると $\left(2_{\mathrm{a}}\right)$ が えられた。nーヘキサンから再結晶して m.p. 115 $117^{\circ} \mathrm{C}$ (文嗝值 $117^{\circ} \mathrm{C}^{2}$ )。

$\begin{array}{llll}\text { 分析值 } & \mathrm{C} 67.39 \% & \mathrm{H} 4.63 \% & \mathrm{~N} 12.33 \% \\ \text { 計算値 } & \mathrm{C} 67.68 \% & \mathrm{H} 4.81 \% & \mathrm{~N} 12.14 \% \\ \left(\mathrm{C}_{13} \mathrm{H}_{11} \mathrm{ClN}_{2}\right) & \mathrm{C} .68 \% & & \end{array}$

ほぼ同様な方法で 表 1 に示す N-アリールアミジン を合成した。このさい, アミン: ニトリル：塩化アルミ ニウム $=1: 1: 1 \sim 1.2$ のモル比で用い, 溶媒のテトラク ロルエタンは使用したニトリルの 5 6 重量倍用いた。 しかし, 後処理が幾分異なっている。すなわち， $\left(2_{\mathrm{b}}\right)$ は塩酸ガスを通じてから溶剤を留去し, 残留物を希塩酸 で抽出してえたものであり，(2 $\left.2_{\mathrm{c}}\right)$ は塩酸 ガスを通じて
から，これを水で抽出してえたものである。 $\left(2_{\mathrm{d}}\right)$ は $\left(2_{\mathrm{a}}\right)$ と全く同様にして，(2 $\left.2_{\mathrm{e}}\right)$ と $\left(2_{\mathrm{f}}\right)$ は塩酸ガスを通じるこ となしに，そのまま溶剤を留去してえた。また，(2g） $\left(2_{\mathbf{h}}\right)$ および $\left(2_{\mathbf{i}}\right)$ は塩酸ガスを通じ, アミジンの塩酸塩 を沈澱としてえたものである。

\section{5-クロル-2-フェニルベンズイミダゾールおよび} 類似化合物の合成 $\quad\left(2_{\mathrm{a}}\right) 2 \mathrm{~g}$ を $50 \%$ メチルアルコー ル $40 \mathrm{~m} l$ に溶解し, 少量の濃塩酸を加えて $\mathrm{pH} 4$ 〜 5 に した。これに次亜塩素酸ナトリウム水溶液（10\%活性塩 素）を、ヨウ化カリウム・デンプン紙が青色を呈するま で加えた。これに $6 \mathrm{~m} l$ を必要とした。このまま $10 \mathrm{~min}$ 間かきまぜ，さらに，炭酸ナトリウム $2 \mathrm{~g}$ の飽和水溶液 を加え，かきまぜながら $1 \mathrm{hr}$ 間還流募沸して析出した 沈澱を口過した。収量 $1.9 \mathrm{~g}$, 収率 $96 \%$ 。ベンゼンから 再結晶して m.p. $210 \sim 212^{\circ} \mathrm{C}$ 文献值 $\left(210^{\circ} \mathrm{C}^{6}\right)$ 。

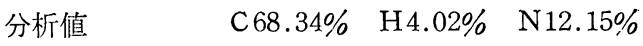
計算值 $\left(\mathrm{C}_{13} \mathrm{H}_{9} \mathrm{C} ! \mathrm{N}_{2}\right) \mathrm{C} 68.28 \% \quad \mathrm{H} 3.97 \% \quad \mathrm{~N} 12.27 \%$. ほぼ同栐な方法で 表 2 に示すベンズイミダゾールを 合成したが，アミジンの塩酸塩を原料として用いた場合 は，これを $50 \%$ メチルアルコールに溶解してから，濃 塩酸を加えずに, ただちに次亜塩素酸ナトリウム水溶液 を加えて反応させたものである。

\section{III. 総 括}

Grenda らが提唱した方法を応用して，9種類の Nアリールアミジンおよび 9 種類のベンズイミダゾールを 合成した。このうち， $\left(2_{\mathrm{d}}\right),\left(2_{\mathrm{f}}\right)$ 抢よび5-クロル-2- $\left(2^{\prime}-\right.$ ナフチル)-ベンズイミダゾールは文献末記載の新化合物

表 $1 \mathrm{~N}-$ リリールナミジン

\begin{tabular}{|c|c|c|c|c|c|c|c|c|}
\hline \multicolumn{3}{|c|}{ N-アリールアミジン (2) } & \multirow{2}{*}{ 収率*1)\% } & \multirow{2}{*}{ m.p. ${ }^{\circ} \mathrm{C}^{* 2)}$} & \multirow{2}{*}{ 再結晶溶媒 } & \multicolumn{3}{|c|}{ 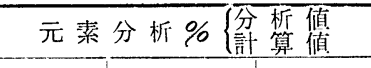 } \\
\hline 号 & $\mathrm{R}_{1}$ & $\mathrm{R}_{2}$ & & & & $\mathrm{C}$ & $\mathrm{H}$ & $\mathrm{N}$ \\
\hline$\left(2_{\mathrm{b}}\right)$ & $\mathrm{CH}_{3}$ & $\mathrm{C}_{6} \mathrm{H}_{5}$ & 82 & $\left.99 \sim 101\left(98 \sim 99^{3}\right)\right)$ & nーヘ キ サン & $\begin{array}{l}80.19 \\
79.96\end{array}$ & $\begin{array}{l}6.96 \\
6.71\end{array}$ & $\begin{array}{l}13.57 \\
13.33\end{array}$ \\
\hline$\left(2_{c}\right)$ & $\mathrm{H}$ & $\mathrm{C}_{6} \mathrm{H}_{5} \mathrm{CH}_{2}$ & 73 & $133 \sim 135\left(138^{4)}\right)$ & ベン ゼン & $\begin{array}{l}79.76 \\
79.96\end{array}$ & $\begin{array}{l}6 \cdot 99 \\
6.71\end{array}$ & $\begin{array}{l}13.25 \\
13.33\end{array}$ \\
\hline$\left(2_{\mathrm{d}}\right)$ & $\mathrm{Cl}$ & $" \prime$ & 63 & $114.5 \sim 116.5$ & nーヘキサン & $\begin{array}{l}68.45 \\
68.71\end{array}$ & $\begin{array}{l}5.65 \\
5.35\end{array}$ & $\begin{array}{l}11.47 \\
11.45\end{array}$ \\
\hline$\left(2_{\mathrm{e}}\right)$ & $\mathrm{H}$ & $2-\mathrm{C}_{10} \mathrm{H}_{7}$ & 68 & $166 \sim 169\left(163 \sim 164^{5}\right)$ & $\begin{array}{l}50 \% \times チ ル ア \\
\text { ルコールさら } \\
\text { にベンゼン }\end{array}$ & $\begin{array}{l}83.02 \\
82.89\end{array}$ & $\begin{array}{l}6.03 \\
5.73\end{array}$ & $\begin{array}{l}11.36 \\
11.38\end{array}$ \\
\hline$\left(2_{\mathrm{f}}\right)$ & $\mathrm{Cl}$ & $"$ & 71 & $189 \sim 192$ & ベンゼン & $\begin{array}{l}73.02 \\
72.73\end{array}$ & $\begin{array}{l}4.89 \\
4.67\end{array}$ & $\begin{array}{l}9.90 \\
9.98\end{array}$ \\
\hline$\left(2_{\mathbf{g}}\right)$ & $\mathrm{H}$ & $\mathrm{P}-\mathrm{CH}_{3} \mathrm{C}_{6} \mathrm{H}_{4}$ & 81 & $152 \sim 154\left(152.5^{2)}\right)$ & nーヘキサン & $\begin{array}{l}80.11 \\
79.96\end{array}$ & $\begin{array}{l}6.88 \\
6.71\end{array}$ & $\begin{array}{l}13.43 \\
13.33\end{array}$ \\
\hline$\left(2_{h}\right)$ & $\mathrm{Cl}$ & $"$ & 94 & $142 \sim 144\left(144.5^{2)}\right)$ & - $n$-ヘ キサン & $\begin{array}{l}68.98 \\
68.71\end{array}$ & $\begin{array}{l}5.60 \\
5.35\end{array}$ & $\begin{array}{l}11.67 \\
11.45\end{array}$ \\
\hline$\left(2_{\mathrm{i}}\right)$ & $\mathrm{CH}_{3}$ & " & 93 & $111 \sim 113\left(115^{2)}\right)$ & $n$-ヘキサン & $\begin{array}{l}80.95 \\
80.32\end{array}$ & $\begin{array}{l}7.47 \\
7.19\end{array}$ & $\begin{array}{l}12.77 \\
12.49\end{array}$ \\
\hline
\end{tabular}

*1）ニトリルを基準とした。

*2) ( ) 内は文献值去す。 
*1)()内は文献値を示す。

*2) 60 65\%メチルアルコールに溶解して用いた。

である。Nアリールアミジンの塩酸塩の $50 \%$ ×ルア ルコール溶液に次亜塩素酸ナトリウム水溶液を加えた場

合,ただちにN - クロルアミジンが生成するが, これを 単離することは, 比較的困難であるために行っていな い。多くの場合反応系中で油状物質として存在してい

る。しかし, ( 2f ) から5一クロルー2- (2' - ナフチル)-ベン ズイミダゾールを合成した場合は, 中間のN - クロルア ミジンが樹脂状物質として存在し, 以後の操作を困難に したので,かき出し, 少量の熱メチルアルコールに溶解 し、ふたたび反応容器に返して反応系中に分散させてか ら炭酸ナトリウム飽和水溶液で処理した。また, えられ たベンズイミダゾールは多くの場合, ほとんど精製を必 要としないほど純粋な゙状態でえられた。これは らの方法が他の多くの方法に較べて優れていることを示 すものであるが,ただ例外として, 2- (P-トリール)-ベ ンズイミダゾールの場合のみはカッ色樹脂状物質として えられたので, これを熱メチルアルコールに溶解し, 水 に分散させて,ふふたたび炭酸ナトリウム水溶液で処理し てえた。また,ナフチル基を置換基として有するベンズ イミダゾールは比較的強いケイ光を有し,ベンジル基を 有するものは比較的弱いケイ光を有することが観察され
た。

\section{文献}

1) V.J. Grenda, R.E. Jones, G. Gal, H. Sletzing-

er, J. Org. Chem. 30259 (1965)2) P. Oxley, W.F. Short, J. Chem. Soc. 1949453

USP 2,451,779 (1948)3) 5. Robev, C.A. 5013838 (1956)4) R. Delaby, P. Raynaud, F. Lilly, Bull. Soc. Chim. France 19612067

5) S. Robev, C.A. 5518676 (1961)6) M.W. Partridge, H.A. Truner, J. Chem. Soc.

1958 20867) B.A. Porai-Koshits, G.M. Kharkharova, C.A.

508608 (1956)8) B.A. Porai-Koshits, G.M. Kharkharova, ibid.

4913224 (1955)9) H.D. Brown et al., J. Am. Chem. Soc. 831764

(1961)10) A.I. Kiprianov, V.A. Shrubovich, C.A. 549956

(1960)11) N.V.S. Rao, C.V. Ratnam, ibid. 5318012 (19

59)12) P.R. Thomas, G.J. Tyler, J. Chem. Soc. 1957

2197 